\author{
KATARZYNA KAROLINA PELS \\ Pracownia Neuromorfologii Molekularnej i Syetemowej \\ Instytut Biologii Doświadczalnej im. M. Nenckiego PAN \\ Pasteura 3, 02-093 Warszawa \\ E-mail:k.pels@nencki.edu.pl
}

\title{
O MOLEKULARNEJ PATOGENEZIE STRESU I DEPRESJI
}

\section{DEPRESJA - RYS HISTORYCZNY}

Najwcześniejsze doniesienia opisujące zaburzenia, jakie dzisiaj określamy mianem depresji, pochodza $z$ drugiego tysiaclecia p.n.e. $z$ obszaru Mezopotamii. Mówią one o pewnym stanie duchowym, będącym skutkiem opętania człowieka przez demony, a „leczonym" m.in. przez bicie lub głodzenie (REYNOLDS i WILSON 2013). W starożytnej Grecji i Rzymie część medyków dopatrywała się przyczyn depresji w biologii i psychice człowieka, dlatego stosowali zupełnie inne metody leczenia, oparte na wykonywaniu czynności relaksujących i spożywaniu leków zawierających wyciag $z$ maku. W Grecji głównym przedstawicielem tej myśli był Hipokrates. Uważał on, iż depresja, zwana wówczas melancholią, powodowana jest zaburzeniem równowagi w czterech płynach ustrojowych: żółtej żółci, czarnej żółci, flegmie $i$ krwi. $Z$ kolei rzymski filozof Cycero przyczyn melancholii dopatrywał się w złości, strachu i żalu (TIPTON 2014).

W średniowieczu życie społeczeństw podporzadkowane było religii, a wszelkie zaburzenia, w tym depresję, ponownie zaczęto przypisywać działaniu diabła, demonów lub czarownic. Osoby chore były izolowane, bądź „leczone” przez odprawiane egzorcyzmy lub nawet palone na stosie.

W czasach Renesansu ponownie rozpoczęto poszukiwania przyczyn depresji w uwarunkowaniach naturalnych. W $1621 \mathrm{r}$. Robert Burton opublikował ksiażkę Anatomia melancholii, w której jako przyczyny depresji wymienił czynniki społeczne (bieda, samotność) i psychiczne (strach). Osobom chorym zalecał diete, ćwiczenia i upuszczanie krwi (BRINK 1979). W okresie Oświecenia depresję uważano za chorobę dziedziczna, a dotknięte nia osoby izolowano od społeczeństwa (RöSSLER 2016).

W wiekach XIX i XX znacznie pogłębiono wiedzę dotycząca zaburzeń psychicznych, w tym depresji. Wyróżniono inne jednostki chorobowe, np. zaburzenia dwubiegunowe opisane przez Emila Kraepelina w 1895 r. W 1917 r., w oparciu o tzw. teorie psychodynamiczna, Zygmunt Freud opracował terapię, nazwana psychoanaliza (MONDIMORE 2005, De SOUSA 2011).

Ruch behawiorystyczny w psychologii postulował, iż depresja powodowana była zachowaniami wyuczonymi, których można się po prostu oduczyć. W latach 60. i 70. XX w. pojawily się pierwsze poznawcze teorie depresji mówiące, iż przyczyna choroby jest sposób interpretowania przez daną osobę negatywnych zdarzeń oraz postrzeganie siebie, jako istoty zupełnie bezradnej (GAUDIANO 2008). Przyczyn depresji doszukiwano się także w czynnikach fizjologicznych, co oznaczało, iż w jej leczeniu pomocne moga być nie tylko psychoterapia, ale także farmaceutyki.

\section{WSPÓŁCZESNA DEFINICJA DEPRESJI}

Zgodnie $z$ definicją Amerykańskiego Towarzystwa Psychiatrycznego, depresja (ang. major depressive disorder, MDD) jest częstą i poważna choroba wpływajaca negatywnie na wiele aspektów życia, nie tylko na samopoczucie, sposób myślenia i zachowanie osoby chorej, ale także na funkcjonowanie

Słowa kluczowe: depresja, glukokortykoidy, leczenie depresji, oś HPA, stres, zaburzenia układu serotonergicznego, zmiany epigenetyczne $\mathrm{w}$ depresji 
całych społeczeństw. Depresja zaliczana jest do kategorii zaburzeń psychicznych i charakteryzuje się współwystępowaniem różnego rodzaju objawów klinicznych: (i) zaburzeń afektywno-poznawczych (występowanie tzw. nastroju depresyjnego, poczucie beznadziejności i bezwartościowości, nadmierne poczucie winy, aż do tak drastycznych jak myśli samobójcze), (ii) zaburzeń neurowegetatywnych (zaburzenia snu, apetytu, osłabienie koncentracji, brak energii), (iii) zaburzeń behawioralnych (anhedonia, czyli obniżona zdolność lub nawet niezdolność do odczuwania przyjemności i radości z czynności uważanych wcześniej za przyjemne, np. spotkań z przyjaciółmi, poczucie braku celu i niezdolności do funkcjonowania $\mathrm{w}$ społeczeństwie) (AMERICAN PSYCHIATRIC ASSOCIATION 2013a). Wymienione objawy moga wykazywać duża różnorodność i zmienne nasilenie u poszczególnych osób, co znacznie utrudnia prawidłowa diagnoze depresji.

Obecnie za podstawę rozpoznania tej choroby uznaje się wywiad lekarski według kryteriów ustalonych przez Amerykańskie Towarzystwo Psychiatryczne (dokładne kryteria diagnozy zawarte sa w: Diagnostic and Statistical Manual of Mental Disorders, wyd. 5, wydana po raz pierwszy w 2013 r.). Obecność depresji stwierdzana jest w przypadku występowania, w ciagu 2 tygodni, pięciu lub więcej objawów, spośród wymienionych powyżej, które w znacznym stopniu wpływaja negatywnie na życie pacjenta. Warunkiem koniecznym jest obecność nastroju depresyjnego lub anhedonii, a także wykluczenie możliwości powiązania obserwowanych objawów $z$ przyjmowanymi lekami, czy też występowaniem innych zaburzeń psychicznych (np. schizofrenii) lub somatycznych.

Należy jednak zauważyć, iż prawidłowo postawiona diagnoza to dla pacjenta zaledwie część kuracji. Podstawowy problem w przypadku leczenia depresji stanowi brak skutecznego i uniwersalnego leku. Z uwagi na nieznane patomechanizmy rozwoju tej choroby nie jest możliwe, aby opierając się jedynie na obserwowanych objawach, skutecznie ocenić, który $z$ dostępnych obecnie sposobów leczenia da najlepsze efekty $\mathrm{w}$ przypadku konkretnego pacjenta. Wybór ten jest bardzo ważny, ponieważ na pierwsze efekty leczenia trzeba czekać dość długo, bo ponad 4 tygodnie (patrz niżej). W pierwszej fazie, farmaceutyki zwiększaja głównie aktywność pacjenta, a dopiero później następuje poprawa nastroju. Opracowania statystyczne wskazują, iż właśnie w pierwszej fazie działania leku dochodzi do największej liczby samobójstw wśród osób cierpiących na depresję. Niemal $15 \%$ osób podejmuje udane próby samobójcze. $Z$ tego względu

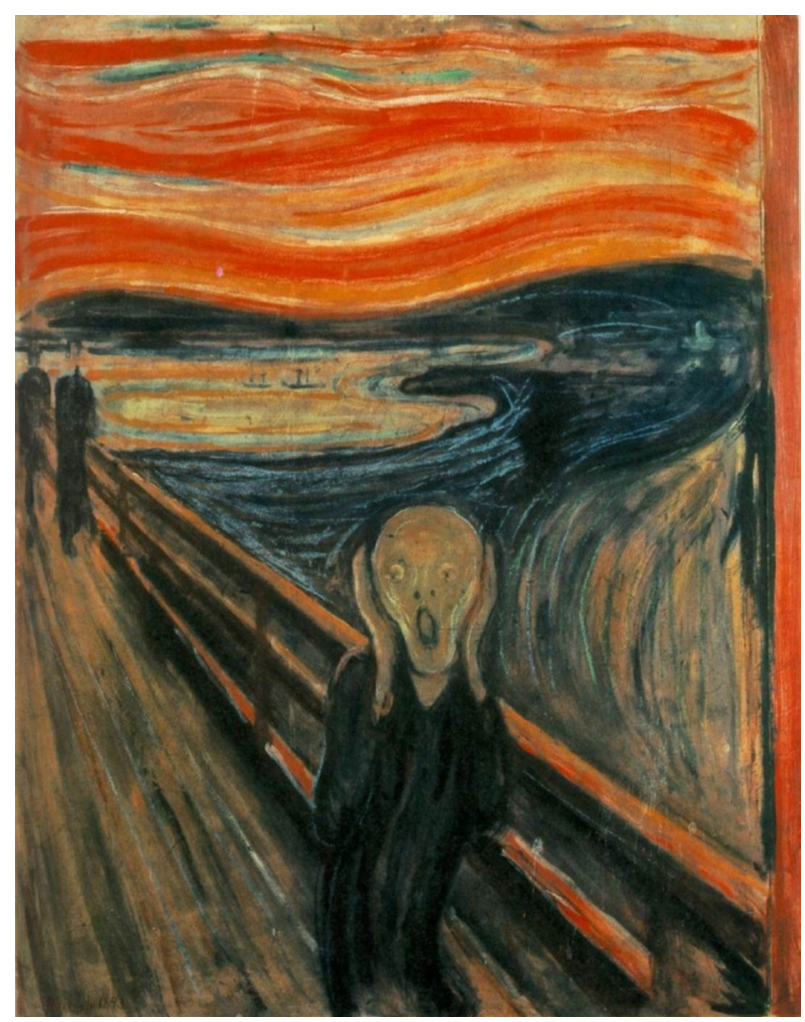

Ryc. 1. Jeden $z$ najbardziej znanych obrazów Edvarda Muncha „Krzyk” według krytyków sztuki przedstawia człowieka przepełnionego bólem egzystencjalnym, co może być utożsamiane $z$ niemym krzykiem osoby zmagającej się $z$ depresją (źródło reprodukcji: Wikipedia, link: https://pl.wikipedia. org/wiki/Krzyk_(obraz)\#/media/Plik:The_Scream. jpg).

depresję uważa się za chorobę śmiertelna (SOBOCKI i współaut. 2006).

\section{DEMOGRAFIA DEPRESJI}

Depresja to choroba wpływająca na życie całych społeczeństw (Ryc. 1). Dane Światowej Organizacji Zdrowia (ang. World Health Organization, WHO) mówia już o prawdziwej „epidemii”, jeśli chodzi o zachorowalność na depresję. Szacuje się, iż obecnie co trzecia osoba na świecie (w tym ponad półtora miliona ludzi w Polsce) zmaga się lub będzie się zmagać $z$ ta choroba, co czyni ja jedna $z$ wiodacych przyczyn niepełnosprawności (FRIEDRICH 2017, WORLD HEALTH ORGANIZATION 2017). Ze względu na to, iż depresja wpływa negatywnie na funkcjonowanie chorego, bardzo często uniemożliwia to wykonywanie przez niego pracy zawodowej. Biorac pod uwage przewidywania WHO, iż depresja do 2030 r. stanowić będzie główna przyczynę niepełnosprawności na świecie, nietrudno wyobrazić sobie jak olbrzymie obciażenie dla rozwoju ekonomicznego państw stanowić 
będzie tak duża liczba osób niezdolnych do pracy. Już teraz szacunkowe dane w skali świata mówią o ponad trzech trylionach dolarów rocznego obciążenia budżetu państw, wynikajacego $z$ kosztów leczenia depresji, a także strat związanych $z$ niezdolnościa do pracy osób chorych (SoBOcKI i współaut. 2006).

\section{RODZAJE DEPRESJI}

Depresja nie jest choroba jednorodną. Obecnie wyróżnia się wiele czynników, które moga przyczynić się do jej etiologii. Ogólnie można stwierdzić, że do rozwoju depresji najczęściej przyczyniają się traumatyczne wydarzenia $z$ życia danej osoby, prowadzace do biochemicznych i morfologicznych zmian zachodzących w mózgu. W zależności od wywołującego ją czynnika bądź charakterystycznych objawów, można wyróżnić kilka typów zespołów depresyjnych.

Depresja (MDD), opisana w pierwszym rozdziale niniejszej pracy, objawia się występowaniem co najmniej dwóch $z$ wyżej wymienionych objawów (m.in. anhedonii, nastroju depresyjnego) przez przynajmniej 2 tygodnie. Choroba ta zaliczana jest do tzw. zaburzeń afektywnych jednobiegunowych. Oznacza to, że pacjent doświadcza tylko objawów charakterystycznych dla depresji, rozumianej jako obniżenie nastroju uniemożliwiajace normalne funkcjonowanie. Jeśli epizody depresji występuja naprzemiennie $Z$ epizodami manii, czyli patologicznie podwyższonego nastroju, mamy do czynienia $z$ zaburzeniami afektywnymi dwubiegunowymi. Nazwa pochodzi od objawów zupełnie sobie przeciwstawnych, znajdujacych się niejako na dwóch biegunach: depresji, czyli obniżonego nastroju, oraz manii, której epizodom towarzyszy pobudzenie, nadmierna aktywność, nieodpowiedzialne zachowanie, często również wybuchy agresji (AMERICAN PSYCHIATRIC AsSOCIATION 2013b).

Klasyfikacja diagnostyczna Amerykańskiego Towarzystwa Psychiatrycznego (DSM-IV-TR) wyróżnia kilka podtypów zespołów MDD. Depresja melancholiczna (tzw. typowa) charakteryzuje się występowaniem anhedonii, utrata masy ciała, pogorszeniem nastroju w godzinach porannych i przedwczesnym porannym budzeniem się. Inny rodzaj stanowi depresja atypowa (tzw. odwrócona). Ta $z$ kolei charakteryzuje się nadmierna sennościa, zwiększonym łaknieniem i gorszym samopoczuciem wieczorem. Ze względu na czas występowania wyróżnia się depresję krótkotrwała nawracajaca, trwająca kilka dni i pojawiajaca się średnio raz w miesiaccu. Depresja sezonowa, jako seria pojawiajacych się i ustępujących epizodów depresyjnych, występujących zazwyczaj jesienią i zima, jest reakcją organizmu na zmniejszenie ilości światła słonecznego. O dystymii, czyli depresji o przebiegu przewlekłym można mówić, gdy występujace pełne kryteria diagnostyczne dla epizodu depresyjnego utrzymuja się minimum dwa lata.

Śmierć bliskiej osoby może także stać się przyczyna depresji. Jeśli typowe objawy trwaja dłużej niż dwa miesiace, mówimy o depresji będacej reakcja na żałobę. $Z$ depresja poporodowa natomiast, mamy do czynienia u kobiet, u których epizod depresyjny zdiagnozowany został około czwartego tygodnia po porodzie. Depresje maskowana, jak sama nazwa wskazuje, rozpoznajemy, kiedy zespól depresyjny jest maskowany przez inne objawy chorobowe, takie jak zaburzenia lękowe, zespół obsesyjno-kompulsywny czy nadużywanie alkoholu. Depresja psychotyczna wiąże się $z$ występowaniem urojeń i omamów, a depresja w wieku starczym powoduje znaczne upośledzenie procesów poznawczych, tzw. pseudootępienie depresyjne (często odwracalne na skutek leczenia, w przeciwieństwie do otępienia występującego w chorobach neurodegeneracyjnych).

Innym rodzajem depresji jest tzw. depresja indukowana lekami (w literaturze anglojęzycznej znana jako „drug-induced depression"). Do jej rozwoju prowadzić może zarówno nadużywanie substancji uzależniajacych, np. kokainy, alkoholu, jak również przyjmowanie niektórych leków. Wśród nich są agoniści receptorów glukokortykoidowych, np. deksametazon (udział glukokortykoidów w patogenezie depresji patrz „Stres, a depresja", poniżej). Leki te wykazuja silne działanie przeciwzapalne, przeciwalergiczne i immunosupresyjne. $Z$ tego powodu stosowane sa do dziśs w leczeniu astmy, alergii, zapalenia stawów, a także u pacjentów po wykonanym przeszczepie. Ze względu na ich skuteczność i brak zamienników, farmaceutyki te stosowane sa pomimo dowodów potwierdzajacych ich działanie prodepresyjne. Pierwsze doniesienia na ten temat pojawiły się w literaturze medycznej już w latach 40 . $\mathrm{XX}$ w. Dzisiaj, znajac lepiej działanie glukokortykoidów, wiemy, iż moga one wywoływać epizody manii albo hipomanii, kiedy ich stosowanie jest stosunkowo krótkotrwałe oraz prowadzić do rozwoju pełnych objawów depresji, przy długotrwałym stosowaniu. Znamy także leki, które moga zmniejszać negatywne efekty przyjmowania glukokortykoidów, np. sole litu (BROWN 2009).

Podsumowujac, depresja jest choroba dotykająca znaczną część społeczeństwa. Dodatkowo do jej rozwoju może przyczynić się wiele różnych czynników. Dlatego nie ulega wątpliwości, iż prowadzenie badań dotyczą- 
cych poznania przyczyn i mechanizmów rozwoju depresji, a także opracowanie skutecznego leczenia jest niezwykle ważne. Najpierw jednak, zastanówmy się co już wiadomo na temat przyczyn postawania tej choroby.

\section{ETIOLOGIA DEPRESJI}

W patogenezę depresji zaangażowane sa zmiany na wielu poziomach, zarówno zmiany w obrębie całych szlaków sygnałowych, tworzacych je białek, jak również genów kodujacych konkretne białka, czy wreszcie zmian epigenetycznych wpływajacych na regulację ekspresji genów. Każdy $z$ tych czynników stanowi mała cząstkę składającą się na podłoże depresji. Obecnie wiemy, że depresja jest choroba dziedziczną. Badania bliźniąt pozwoliły na oszacowanie dziedziczności tej choroby na poziomie 30-37\%, w zależności od parametrów branych pod uwagę podczas analiz (MCGUFFIN i wspó1aut. 2007, MENKE i współaut. 2012). Pomimo tego, do dzisiaj nie znamy genetycznych uwarunkowań depresji, nie wiemy też, jakie geny sa bezpośrednio odpowiedzialne za jej powstawanie. Nie potrafimy wskazać $z$ całkowita pewnością, które ze zmian genetycznych predysponuja do zwiększonego ryzyka zachorowalności (KRISHNAN i NESTLER 2008). Częściowo może to wynikać $z$ faktu, iż na patogenezę depresji maja wpływ nie tylko czynniki genetyczne, ale także epigenetyczne, środowiskowe oraz czynniki wynikajace $z$ osobowości danej osoby i jej podatności na zachorowanie (MANN i CURRIER 2006, HAYLEY i LiTTLELJOH 2013). To właśnie sprawia, że zrozumienie molekularnych podstaw depresji jest znacznie trudniejsze $w$ porównaniu $z$ innymi wieloczynnikowymi chorobami, jak np. cukrzyca czy rak (KRISHNAN i NESTLER 2010).

\section{UDZIAE SEROTONINY W PATOGENEZIE DEPRESJI}

Odpowiedź na pytanie o przyczynę depresji wciąż jest niejednoznaczna. Wypracowanie jednej, ogólnej teorii mogącej wyjaśnić patogeneze wszystkich diagnozowanych zespołów depresyjnych jest niezwykle trudne, głównie ze względu na ich heterogenność, jak również brak jednoznacznych kryteriów diagnostycznych.

Istnieje wiele hipotez starających się wyjaśnić etiologię depresji. Jedną $z$ najpopularniejszych, choć bardzo uproszczoną, jest teoria tzw. chemicznej nierównowagi w mózgu. Ta, mająca już niemal 50 lat hipoteza zakłada, iż deficyty w przekaźnictwie synaptycznym monoamin (serotoniny, noradrenaliny i dopaminy) stanowią źródło wspomnianej nierównowagi chemicznej, a co za tym idzie sa główna przyczyna depresji (FRANCE i współaut. 2007). Choć teoria ta została podważona (WAINWRIGHT i GALEA 2013), jednak na uwage zasługuje udział jednej $Z$ monoamin - serotoniny (5-hydroksytryptamina, w skrócie 5-HT) w patogenezie depresji. Serotonina, nazywana także „hormonem szczęścia", to organiczny związek chemiczny zaliczany do amin biogennych. Produkowana jest w komórkach błony śluzowej jelit, pewnych częściach mózgu (jądra szwu, szyszynka) i w trombocytach. Serotonina bierze udział w procesach krzepnięcia krwi, jak również pełni istotna rolę $\mathrm{w}$ regulacji czynności przewodu pokarmowego, przez wpływ na ruchy jelit. W przypadku spożycia szkodliwej substancji, serotonina, wpływając na przyspieszenie pracy jelit, powoduje nudności i wymioty, a tym samym przyczynia się do wydalenia tej substancji $z$ organizmu. Jednak funkcją serotoniny, działajacej także jako neuroprzekaźnik, szczególnie istotna dla patogenezy depresji, jest jej wpływ na regulację snu, apetytu i nastroju człowieka. Serotonina ma związek $z$ odczuwaniem przez nas pozytywnych emocji, takich jak szczęście, spokój i bezpieczeństwo. Wykazano, iż przyjemność odczuwana po spożyciu egzogennych substancji psychoaktywnych wynika częściowo $z$ wywołanego przez nie, zwiększonego uwalniania 5-HT. Serotonina może także redukować uczucie niepokoju i lęku (MOHAMMAD-ZADEH i współaut. 2008).

Liczne badania kliniczne i badania na zwierzętach potwierdziły udział zaburzeń układu serotonergicznego w patogenezie depresji (CARR i LUCKI 2010). Wykazano, że u pacjentów ze zdiagnozowana depresja dochodzi do zmniejszenia ilości L-tryptofanu w osoczu krwi. Tryptofan $z$ kolei jest prekursorem serotoniny, dlatego zmniejszenie jego dostępności przekłada się bezpośrednio na zmniejszoną syntezę 5-HT (MAES i współaut. 1990). Za zbyt niski poziom serotoniny odpowiadaja również zaburzenia w samym przekaźnictwie synaptycznym pomiędzy komórkami nerwowymi. Tutaj główna przyczyna sa mutacje i polimorfizmy w obrębie transporterów (GRYGLEWSKI i współaut. 2014) i receptorów dla serotoniny (JANS i współaut. 2007) prowadzace do dysfunkcji tych białek. Wykazano, iż obniżenie aktywności jednego $z$ receptorów $\left(5-\mathrm{HT}_{1 \mathrm{~A}}\right)$ może stanowić marker depresji (BHAGWAGAR i współaut. 2004, HIRVONEN i współaut. 2008). Receptor ten pełni kluczowe funkcje w regulacji przekaźnictwa serotonergicznego, wpływajac na regulację ujemnego sprzężenia zwrotnego osi podwzgórze-przysadka-nadnercza (ang. hypothalamic pituitary adrenal axis, HPA axis; działanie osi HPA opisałam w rozdziale "Czy stres może prowadzić do depresji?"). Na za- 
burzenia pracy receptora $5-\mathrm{HT}_{1 \mathrm{~A}}$ szczególnie narażone sa obszary limbiczne mózgu, odpowiedzialne za zachowania afektywne. Dodatkowo wykazano, że polimorfizmy występujące $\mathrm{w}$ regionie promotorowym $5-\mathrm{HT}_{1 \mathrm{~A}}$ sa ściśle powiazane $z$ depresja i podejmowanymi próbami samobójczymi (LE FRANCOIS i współaut. 2008).

Wykazano także, że zmniejszenie ilości serotoniny może powodować przejściowe zaburzenia depresyjne u osób zdrowych, ze skłonnością do rozwoju depresji (NEUMEISTER i współaut. 2004). Z drugiej strony, patologiczne skutki zmniejszenia ilości tryptofanu są znacznie wyraźniejsze u pacjentów, u których dochodziło do nawrotów depresji, w porównaniu do osób zdrowych, znajdujacych się w grupie zwiększonego ryzyka, m.in. ze względu na występowanie depresji u członków rodziny (RUHÉ i współaut. 2007). Biorąc pod uwagę powyższe fakty, przypuszczać można, iż zaburzenia funkcji 5-HT sa związane nie tylko $z$ rozwojem MDD, ale także z możliwością remisji choroby (BHAGWAGAR i COWEN 2008, WiCHERs i współaut. 2010, Cowen 2015). Co ciekawe, niedawne analizy pokazały brak istotnych statystycznie zmian w ekspresji genów zaangażowanych w szlak serotonergiczny, w dużej populacji osób chorych na depresję (HowARD i współaut. 2019).

Jednak inne badania wykazały zwiazek pomiędzy obniżeniem poziomu L-tryptofanu w osoczu krwi osób z ciężka formą depresji a obecnością stanu zapalnego w organizmie i aktywacją enzymu metabolizujacego tryptofan (2,3-dioksygenaza indoloaminowa) (ANDERSON i współaut. 1990). Jest to zgodne $z$ obserwowana zmniejszona skutecznością leków antydepresyjnych u pacjentów, u których depresji towarzyszy wysoki poziom biomarkerów zapalnych (UHER i współaut. 2014).

\section{CZY STRES MOŻE PROWADZIĆ DO DEPRESJI?}

Pytanie, czy stres może powodować depresję, $z$ jednej strony wydaje się być pytaniem trywialnym, $z$ drugiej zaś, ma fundamentalne znaczenie dla naszego poznania patogenezy MDD. Jeśli na tak postawione pytanie odpowiemy twierdząco, to wówczas główny nacisk powinien być kładziony nie na leczenie depresji jako takiej, ale na zapobieganie jej powstawaniu przez terapię zaburzeń zwiazanych ze stresem. Badania naukowe wykazały ścisłe powiazanie depresji z zaburzeniami lękowymi. Do rozwoju MDD dochodzi najczęściej w konsekwencji zadziałania czynnika lub sytuacji stresowej. Jednym $z$ najlepiej udokumentowanych zjawisk, jest zwiazek depresji $z$ zaburzeniem dzia- łania osi HPA (O’KEANE i współaut. 2012). Oś ta reguluje uwalnianie hormonów glukokortykoidowych $\mathrm{z}$ kory nadnerczy. W normalnych warunkach, wchodzace w skład osi HPA podwzgórze syntetyzuje i wydziela kortykoliberynę (ang. corticotropin-releasing hormone, CRH). CRH transportowana jest do przedniego płata przysadki, co prowadzi do uwalniania adrenokortykotropiny (ang. adrenocorticotropic hormone, ACTH). Ta $z$ kolei transportowana jest przez krew do kory nadnerczy, skąd wydzielany jest kortyzol, hormon zaliczany do glukokortykoidów (STEPHENS i WAND 2012).

W warunkach fizjologicznego stresu, takiego jak sytuacja „walki lub ucieczki”, wydzielane glukokortykoidy wspieraja organizm wywierając efekt plejotropowy na różne narządy. W mózgu efekt ten charakteryzuje m.in. zahamowanie wydzielania $\mathrm{CRH}$ przez podwzgórze i w konsekwencji zahamowania wydzielania kortyzolu przez korę nadnerczy. Taka odpowiedź organizmu na stres określamy regulacja przez ujemne sprzężenie zwrotne. Ma ona na celu zapobieganie efektom zbyt długiego narażenia organizmu na szkodliwy, podwyższony poziom glukokortykoidów (ORAY i wspólaut. 2016). Niestety, długotrwały stres lub stres ostry o dużym nasileniu, może prowadzić do zaburzenia normalnej pętli sprzężenia zwrotnego, co prowadzi do niekontrolowanego uwalniania glukokortykoidów (DE KLOET i współaut. 1998). Jego konsekwencja sa nieprawidłowości morfologiczne i behawioralne. Dochodzi m.in. do zmniejszenia objętości niektórych struktur mózgu, w tym kory przedczołowej i hipokampa, na skutek nieprawidłowości w kształcie drzew dendrytycznych i synaps neuronów w tych obszarach mózgu (HARRISON 2002). Innym efektem jest niezdolność do odczuwania przyjemności, wynikajacca $z$ zaburzeń w obrębie jądra półleżącego wchodzacego w skład układu nagrody (NARANJO i współaut. 2001).

Dodatkowo, coraz więcej badań podkreśla rolę astrocytów w depresji. Obserwowana w korze przedczołowej i hipokampie atrofia morfologiczna i funkcjonalna tych komórek oraz zmniejszenie ilości markerów astrocytarnych (np. GFAP) sa silnie powiazane $z$ zaburzeniami depresyjnymi (RAJKOWSKA i STOCKMEIER 2013, SKUPIO i współaut. 2015) (dokładny opis zamieściłam w rozdziale "Zmiany morfologiczne makroskopowej i mikroskopowej struktury mózgu w depresji”).

$\mathrm{Na}$ poziomie molekularnym, w regulację działania osi HPA zaangażowane sa dwa typy receptorów: receptor typu I, mineralokortykoidowy (ang. mineralocorticoid receptors, MR) oraz receptor typu II, glukokortykoidowy (ang. glucocorticoid receptors, GR). 
Co ciekawe, kortyzol w warunkach fizjologicznych wykazuje ok. 10-krotnie wyższe powinowactwo do MR niż GR (FULLER i współaut. 2000), natomiast zwiększone stężenie kortyzolu we krwi, będace skutkiem stresu, powoduje jego wiazanie do GR i regulacje odpowiedzi stresowej (HERMAN i współaut. 2016).

Uważa się, iż zaburzenia negatywnego sprzężenia zwrotnego osi HPA, prowadzace do depresji, wynikaja $z$ nieprawidłowej funkcji GR w mózgu (O’KeANe i współaut. 2012). Według hipotezy ilość GR w komórce jest głównym czynnikiem determinującym jej odpowiedź na glukokortykoidy, a tym samym na bodziec stresowy. Jednak mechanizmy komórkowe odpowiedzialne za działanie petli ujemnego sprzężenia zwrotnego regulującej ekspresję genu Nr3c1 kodującego GR wciąż nie sa jasne. GR jest czynnikiem transkrypcyjnym, który może wpływać zarówno dodatnio, jak i ujemnie na ekspresję setek genów. Znajdujący się w cytoplazmie receptor glukokortykoidowy w formie nieaktywnej tworzy kompleks $\mathrm{z}$ białkami szoku cieplnego (ANACKER i współaut. 2011). Po zwiazaniu liganda, czyli pojawiającej się w komórce na skutek stresu cząsteczki hormonu glu- kokortykoidowego, receptor oddysocjowuje $z$ kompleksu i tworzy dimery. Następnie, przy pomocy białek translokacji jadrowej, ulega przemieszczeniu do jadra komórkowego (SMOAK i CIDLOWSKI 2004). Tam wią̇e się ze specyficznymi, zachowanymi ewolucyjnie sekwencjami (ang. glucocorticoid response elements, GREs) zlokalizowanymi w regionach regulatorowych genów. Tak zwane dodatnie sekwencje GREs, po przyłaczeniu sie GR odpowiadaja za zwiększenie transkrypcji danego genu, a tzw. ujemne GREs, odpowiadaja za hamowanie transkrypcji (Ryc. 2) (FARRELl i O'KEANE 2016). Co ciekawe, sam gen $N r 3 c 1$ ma ujemny GRE, co powoduje, że translokacja GR do jadra wywołuje zahamowanie ekspresji tegoż genu. W komórkach nieneuronalnych wykazano, że zwiazanie GR $z$ ujemnym GRE, umiejscowionym $\mathrm{w}$ eksonie $9 N r 3 c 1$, prowadzi do rozległego zapętlenia genu, czego efektem jest przeniesienie ujemnego GRE w pobliże promotora. Rozpoczyna to proces tworzenia kompleksu hamujacego, w skład którego wchodza: GR zwiazany $z$ eksonem 6 oraz białka NcoR1 i HDAC3 zlokalizowane $\mathrm{w}$ miejscu startu transkrypcji genu kodującego GR. Zjawisko to prowadzi do zahamowania transkrypcji Nr3c1 (RAMA-

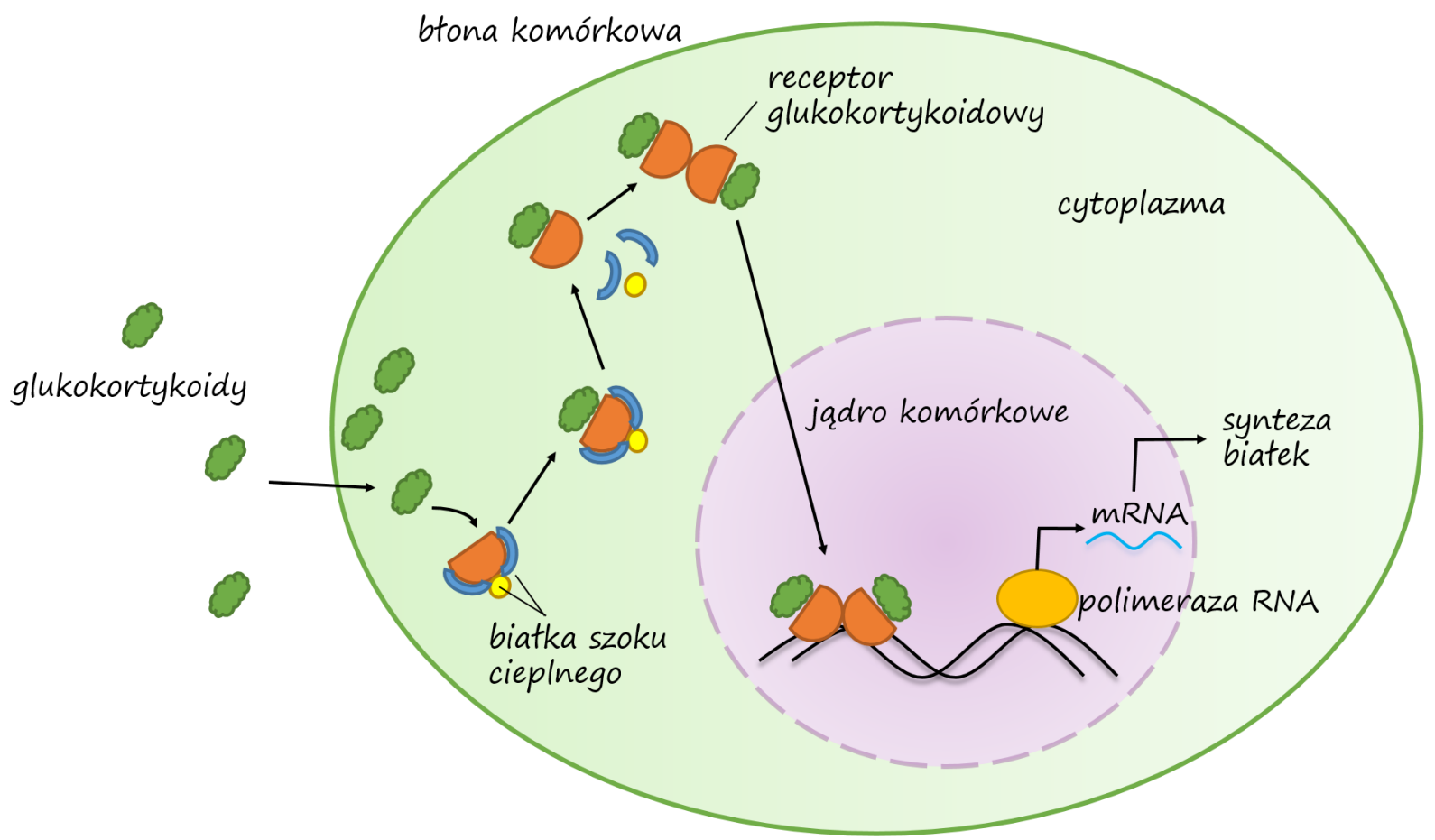

Ryc. 2. Glukokortykoidy pełnią ważną funkcję $\mathrm{w}$ regulowaniu odpowiedzi organizmu na stres, $\mathrm{m} . \mathrm{in}$. poprzez wpływ na ekspresję wielu genów.

Po wniknięciu do komórki wiążą się receptorem glukokortykoidowym (GR), aktywując go poprzez odłaczenie kompleksu inaktywującego (złożonego $z$ białek szoku cieplnego: hsp90 i hsp70). Następnie aktywowany GR tworzy dimery i w takiej postaci transportowany jest do jądra komórkowego, gdzie działa jako czynnik transkrypcyjny. Reguluje ekspresję wielu genów, zarówno dodatnio - zwiększając ich ekspresję, jak i ujemnie. 
MOORTHY i CIDLOWSKI 2013). Jest to przykład mechanizmu epigenetycznego obejmującego zmianę architektury jądra komórkowego, której dysfunkcja może mieć ogromny wpływ na powstawanie depresji.

\section{NEUROTROFICZNA TEORIA POWSTAWANIA DEPRESJI}

Podstawa tej teorii jest udział białka BDNF (neurotroficzny czynnik pochodzenia mózgowego, ang. brain-derived neurotrophic factor) $\mathrm{w}$ patogenezie depresji. Białko to należy do rodziny neurotrofin, reguluje żywotność neuronów, ich wzrost i różnicowanie. W mózgu warunkuje m.in. funkcjonowanie neuronów siatkówki, neuronów cholinergicznych i dopaminergicznych. Ma także kluczowe znaczenie dla plastyczności synaptycznej, $\mathrm{w}$ tym regulacji długotrwałego wzmocnienia synaptycznego (ang. long-term potentation, LTP). Zjawiska te sa ważne dla tworzenia pamięci. Wykazano też, że poza działaniem neuroprotekcyjnym, BDNF jest zaangażowany $\mathrm{w}$ patogenezę depresji $\mathrm{i}$ potencjalne mechanizmy terapeutyczne (LIPSKY i MARINI 2007).

Badania wykazały związek między systemem neurotroficznym a serotonergicznym. U osób zdrowych zaobserwowano, iż zmniejszenie poziomu tryptofanu kompensowane jest przez zwiększenie poziomu białka BDNF. Takiego mechanizmu kompensacyjnego nie obserwowano za to u pacjentów $z$ depresja (NEUMEISTER i współaut. 2005). Dodatkowo pokazano, iż stres może zaburzać działanie BDNF, co prowadzi do zaniku dendrytów, synaps, a nawet całych neuronów. To z kolei może być przyczyna zmniejszenia objętości hipokampa, obserwowanej u pacjentów z depresja (MANn i CURRIER 2006). Powyższe fakty stanowia podstawę teorii neurotroficznej rozwoju depresji.

U osób $z$ depresja dochodzi do zmniejszenia poziomu białka BDNF $\mathrm{w}$ hipokampie i w korze przedczołowej. Co ciekawe, zmiany te sa odwracalne pod wplywem leczenia (SHIMIzU i współaut. 2003, SUN i współaut. 2013). Wykazano w modelach zwierzęcych, iż bezpośrednie podanie BDNF do hipokampa wywołuje efekt antydepresyjny (HAYLEY i LiTTLELJOHN 2013). Natomiast podanie interferonu alfa, cytokiny wywołującej objawy depresji, powoduje obniżenie poziomu białka BDNF oraz zmniejszenie neurogenezy w hipokampie (DEDONI i współaut. 2012, HAYLEY i LiTTLELJOHN 2013). Wykazano także, iż popularnie stosowane leki antydepresyjne oraz terapia oparta na elektrowstrzasach wplywaja pozytywnie na ekspresje genu BDNF i neurogeneze w hipokampie (HAYLEY i LITTLELJOHN 2013). Co ciekawe, podobne efekty wywołuje podanie ketaminy (antagonisty receptorów dla glutaminianu), która, działając poprzez fosforylację białka EF-2, wpływa dodatnio na ekspresje białka BDNF (KAVALALI i MonTEGGIA 2012). Podsumowując, przedstawione doniesienia sugeruja, iż stres prowadzacy do zmniejszenia ekspresji genu $B D N F$, powoduje upośledzenia funkcjonowania układu nerwowego, które moga przyczyniać się do rozwoju depresji (PITTENGER i DUMAN 2008).

\section{CZYNNIKI EPIGENETYCZNE W PATOGENEZIE STRESU I DEPRESJI}

Epigenetyczna regulacja ekspresji genów polega na zmianach $\mathrm{w}$ strukturze chromatyny, nie zwiazanych $z$ modyfikacjami sekwencji DNA. Wśród zmian epigenetycznych najlepiej poznane sa modyfikacje kowalencyjne nukleotydów DNA (np. metylacja), histonów (jak metylacja, czy acetylacja) oraz działanie niekodujacych czasteczek RNA (LOLAK i współaut. 2014). Wykazano, iż na skutek stresu dochodzi do metylacji w obrębie genów: $N r 3 c 1, B D N F$ (ROTH i współaut. 2009) czy FKBP5, kodującego białko biorace udział w regulacji działania glukokortykoidów i osi HPA (BINDER 2009). Metylacja genów zachodzi głównie $w$ obszarach promotorowych i skutkuje hamowaniem ich transkrypcji.

Traumatyczne wydarzenia $z$ dzieciństwa moga odcisnąć swoje piętno na dorosłym życiu danej osoby właśnie przez powstawanie zmian epigenetycznych, a także stanowia czynnik ryzyka dla rozwoju depresji (MANIGLIO 2009). Wykazano m.in. zwiększone ryzyko depresji u kobiet, które jako dzieci były wykorzystywane seksualnie (ALT i współaut. 2010, BALE i współaut. 2010, HEIM i współaut. 2010). U takich osób dochodzi do zmian neuroendokrynnych (np. niewrażliwość na glukokortykoidy) i anatomicznych (zmniejszenie objętości hipokampa) (HEIM i współaut. 2008, HORNUNG i HEIM 2014).

Inny przykład stanowia dzieci pozbawione opieki rodziców i maltretowane. Ciężkie dzieciństwo skutkuje u nich zwiększoną aktywnością osi HPA, zmniejszona ekspresja GR oraz silna metylacja w obrębie promotora $1_{f}$ genu Nr3c1. Wymienione objawy sa typowe dla depresji i niestety skutkuja zwiększonym ryzykiem popełnienia samobójstwa w późniejszym wieku (FERGUSSON i współaut. 1996, WidOM i współaut. 2007). Badania prowadzone na mózgach samobójców, którzy byli maltretowani w dzieciństwie, wykazały metylacje i zmniejszona ekspresje genu Nr3c1 w obrębie hipokampa. Dla porównania, u przypadkowych ofiar wypadków, nie maltretowanych, takich zmian nie obserwowano (MCGOWAN i współaut. 2009). Można 
zatem przypuszczać, iż obecność metylacji i zmniejszona ekspresja genu $N r 3 c 1$ stanowia marker depresji oraz informuja o predyspozycji danej osoby do popełnienia samobójstwa.

Także u gryzoni, które przez kilka miesięcy po urodzeniu były rozdzielone $z$ matka wykazano fenotyp typowy dla depresji (Murgatroyd i współaut. 2009). Dochodziło $\mathrm{u}$ nich do zaburzeń funkcjonowania osi HPA (ARCHER i współaut. 2013), a także zwiększonej metylacji w obrębie promotora $1_{7}$ genu Nr3c1 (odpowiednik promotora $1_{\mathrm{f}} \mathrm{u}$ ludzi). Co istotne, zmiany w metylacji utrzymywały się u nich przez całe życie (SMART i współaut. 2015).

Innym, ważnym, choć wciąż mało poznanym, mechanizmem epigenetycznym sa wielkoskalowe zmiany architektury jadra komórkowego. Do najważniejszych elementów struktury jądra należa terytoria chromosomowe, które są zdekondensowana, lecz $z$ zachowujaca integralność, forma chromosomów mitotycznych. Mniejsze jednostki wchodzace w skład terytoriów chromosomowych to tzw. domeny topologiczne (ang. topologically associated domains, TADs), obejmujace odcinki DNA o długości rzędu miliona par zasad. Wewnattrz domen topologicznych zachodza liczne przestrzenne interakcje między odcinkami DNA, związane $z$ wypętlaniem się nici chromatynowych. Prowadzi to do przemieszczania się sekwencji regulatorowych, np. wzmacniaczy, lub sekwencji wyciszajacych w pobliże regulowanych przez nie genów, które często występują w znacznej odległości od siebie wzdłuż liniowej sekwencji DNA (WILCZYŃSKI 2014, TANG i współaut. 2015). Prowadzone do tej pory badania, w kontekście zmian organizacji chromatyny wewnatrz jądra komórkowego, dotyczyły głównie komórek proliferujacych i/lub ulegających różnicowaniu (SzCZERBAL i współaut. 2009). Niewiele natomiast jest danych dotyczących komórek terminalnie zróżnicowanych, w tym neuronów i komórek glejowych (WILCZYŃSKI 2014). Opublikowane dotychczas badania zawieraja opis morfologiczny przemieszczania się genów na odległości rzędu setek nanometrów (CREPALDI i współaut. 2013, WALCZAK i współaut. 2013) i analize molekularna tworzenia się pętli wpływających na ekspresję opisywanych genów (RAJARAJAN i współaut. 2016). Obecnie wiadomo również, iż wielkoskalowe zmiany struktury chromatyny, przez wpływ na ekspresję genów, moga mieć duże znaczenie patogenetyczne w chorobach neurologicznych, np. w padaczce (WALCZAK i współaut. 2013), czy chorobach psychicznych, np. w schizofrenii (RAJARAJAN i współaut. 2018) i depresji. Podanie zwierzętom deksametazonu (agonisty
GR) powodowało przemieszczanie się genu $N r 3 c 1$ do obszarów skondensowanej, a tym samym nieaktywnej transkrypcyjnie chromatyny, co jest zgodne $z$ obserwacjami dotyczacymi zmniejszenia ekspresji tego genu (Pels i Wilczyński, dane nieopublikowane).

\section{ZMIANY MORFOLOGICZNE MAKROSKOPOWEJ I MIKROSKOPOWEJ STRUKTURY MÓZGU W DEPRESJI}

Wiedza na temat zaburzeń budowy mózgu związanych $z$ depresja pochodzi $z$ badań tkanek ludzkich: autopsyjnych (wykonywanych metodami makro- i mikroanatomicznymi) i przyżyciowych (metodami obrazowymi), a także $z$ badań na modelach zwierzęcych. W materiale pobranym po śmieci pacjenta można dokładnie zmierzyć i zważyć poszczególne części mózgu oraz precyzyjnie zdiagnozować ewentualne nieprawidłowości ich połązeń. Ponadto, dzięki zastosowaniu barwienia histologicznego, czy reakcji immunohistochemicznych odpowiednich dla metod mikroskopowych, możliwe jest określenie wielkości poszczególnych neuronów i komórek glejowych oraz ich zagęszczenia. Niestety praca $Z$ tkankami ludzkimi jest trudna, głównie ze względu na degradacje subtelnych elementów ultrastrukturalnych post-mortem, co znacznie utrudnia lub wręcz uniemożliwia prawidłowa interpretację wyników.

Nieliczne badania wykonane w krótkim czasie po śmierci pacjenta ujawniły pewne zaburzenia struktury komórek nerwowych, np. długości i stopnia rozgałęzienia dendrytów, a także gęstości tzw. kolców dendrytycznych, czyli drobnych wypustek pnia dendrytu o długości do $2 \mu \mathrm{m}$ (PETERS i współaut. 1991, MANJI i współaut. 2001, NiMCHINSKY i współaut. 2002). U części pacjentów zaobserwowano zmniejszenie objętości hipokampa i kory przedczołowej. Wymienione struktury uważane sa za istotne $z$ punktu widzenia patogenezy depresji. Hipokamp (łac. hippocampus) odgrywa ważna rolę w przenoszeniu (konsolidacji) informacji $z$ pamięci krótkotrwałej do pamięci długotrwałej oraz w orientacji przestrzennej. Kora przedczołowa (łac. cortex praefrontalis) pełni funkcję w działaniu pamięci roboczej, planowaniu ruchów i działań oraz rozważaniu ich konsekwencji, a także hamuje spontaniczne i często gwałtowne reakcje emocjonalne. Atrofia dendrytów i kolców dendrytycznych, a $\mathrm{w}$ rezultacie również synaps, w hipokampie i korze przedczołowej, koreluje $z$ pseudootępieniem występującym u osób cierpiacych na depresję. Zmiany atroficzne dendrytów i kolców dendrytycznych występowały głównie w polach rogu Amona (regiony CA1 i CA3; 
łac. cornu ammonis 1 i cornu amonnis 3), w zakręcie zębatym hipokampa (łac. gyrus dentatus) oraz w warstwach II/III kory przedczołowej (DREVETS i FUREY 2009). Interesujacym jest, iż u części osób chorych poddanych leczeniu, dochodziło do odwrócenia (częściowego lub całkowitego) zmian zachodzacych w hipokampie, w tym zwiększenia jego objętości do rozmiarów fizjologicznych (SAPOLSKY 2000). Sugeruje to zaangażowanie procesów plastycznych w patogenezę depresji.

Nie wszystkie struktury mózgu ulegaja zmniejszeniu pod wpływem depresji. Odwrotne zmiany obserwowano w ciele migdałowatym (łac. corpus amygdaloideum) i w jadrze półleżacym (łac. nucleus accumbens) (QIAO i współaut. 2016). Przyczyny zróżnicowania zmian w różnych regionach mózgu nie sa jeszcze poznane. Ze względu na trudności $\mathrm{w}$ stosowaniu mikroskopii elektronowej w tkance mózgu ludzkiego post-mortem znaczna część wiedzy na temat wyżej wymienionych zmian cytologicznych stanowi ekstrapolację wyników uzyskanych w modelach zwierzęcych.

Przyżyciowe obserwacje dynamiki zmian objętości struktur mózgu zachodzacych u ludzi $z$ depresją (także ich odwracalności pod wpływem leczenia), możliwe sa tylko dzięki zastosowaniu nieinwazyjnych metod obrazowania, takich jak tomografia komputerowa lub rezonans magnetyczny (DREVETS i FUREY 2009). Choć wyniki uzyskane przy użyciu tych technik dostarczaja niezwykle cennych informacji, metody te charakteryzują się znacznie mniejsza rozdzielczościa niż mikroskopia.

Pomoc w zrozumieniu patogenezy depresji i zachodzacych pod jej wpływem zmian morfologicznych stanowia badania $z$ wykorzystaniem modeli zwierzecych. Odzwierciedlaja one najważniejsze anomalie behawioralne występujacce u ludzi, tzn. lęk, anhedonię oraz rozpacz (ang. despair), a także, jak wykazano, podobne zmiany cytologiczne neuronów, np. zanik/wzrost dendrytów, kolców dendrytycznych i synaps, zależnie od regionu mózgu (KANG i współaut. 2012).

Co niezwykle interesujace, w tkance mózgu pobranej post-mortem od ludzi cierpiacych na depresję oraz w preparatach mózgu zwierzat poddanych eksperymentom wywołujacym behawioralne zmiany depresyjne zaobserwowano zmniejszenie liczby astrocytów (WANG i współaut. 2017). Komórki te do niedawna były uważane za "podporowe” dla neuronów, bez udziału w zjawiskach zwiazanych z plastycznościa synaptyczną. Współczesne poglądy wskazują na aktywna rolę astrocytów w neurotransmisji i plastyczności (STEINHÄUSER i KETTENMANN 2009, VOLTERRA, 2009), a w szczególności w wychwycie neuroprzekaźników, utrzymaniu homeostazy synaptycznej, regulacji rozwoju synaps (dojrzewanie i ich eliminację), a także utrzymaniu bariery krew-mózg (CHUNG i współaut. 2015). To ostatnie odkrycie wydaje się szczególnie istotne, bowiem bez tej bariery, spożycie mięsa, które normalnie jest nasycone glutaminianem, mogłoby spowodować drgawki, prowadzace nawet do śmierci. Rośnie także liczba publikacji opisujących badania komórkowe i molekularne, wskazujace na zaburzone funkcjonowanie astrocytów w depresji (LEE i współaut. 2007, RAJKOWSKA i STOCKMEIER 2013, SANACORA i BANASR 2013). U pacjentów $z$ depresją dochodzi do atrofii morfologicznej i funkcjonalnej astrocytów, a także zmniejszonej ekspresji markerów astrocytarnych, np. GFAP, s100B, EAAT1, EAAT2 (RAJKOWSKA i STOCKMEIER 2013, SKUPIO i współaut. 2015). Eksperymenty przeprowadzane na szczurach sugeruja, że blokowanie wychwytu glutaminianu $z$ astrogleju jest wystarczające do wywołania zachowań depresyjnych i lękowych (BECHTHOLT-GOMPF i współaut. 2010, CUI i współaut. 2014).

\section{LECZENIE DEPRESJI}

Jak wspomniałam we wstepie, brak znajomości mechanizmów prowadzacych do rozwoju depresji przekłada się na trudności w doborze odpowiedniego leczenia. Przepisane leki często okazuja się nieskuteczne w przypadku indywidualnego pacjenta (CIPRIANI i współaut. 2018). Dane WHO mówią, iż blisko $30 \%$ chorych nie wykazuje poprawy w wyniku zastosowania standardowych leków antydepresyjnych. W takiej sytuacji konieczna jest zmiana sposobu leczenia. Wiaże się to jednak $z$ dodatkowym stresem i dyskomfortem pacjenta oraz może prowadzić do tragicznych skutków, włączajac w nie podejmowanie prób samobójczych.

Stosowane obecnie sposoby leczenia zaliczyć można do jednej $z$ dwóch kategorii: farmakoterapii i psychoterapii. W leczeniu depresji stosowane są także elektrowstrząsy.

Zgodnie $z$ wytycznymi Amerykańskiego Towarzystwa Psychiatrycznego, leki antydepresyjne moga być stosowane jako początkowa metoda leczenia pacjentów, zarówno z łagodna, umiarkowaną, jak i ciężką formą depresji, a także w przypadku nawrotów (AMERICAN PSYCHIATRIC ASSOCIATION 2013a). Jednak skuteczność leków antydepresyjnych nie jest imponujaca. Badania wykazały, że zaledwie u $1 / 3$ pacjentów dochodzi do pełnej remisji choroby po jednej serii leczenia (RUSH i współaut. 2006). Ponadto, leczenie przy zastosowaniu antydepresantów charakteryzuje się opóźnioną odpowiedzią kliniczna, od 4 do 6 tygodni. Powodem tego opóź- 
nienia może być ich pośredniczenie $\mathrm{w}$ długoterminowych procesach, takich jak efekty epigenetyczne (TSANKOVA i współaut. 2007). Wykazano, że leki antydepresyjne moga działać przez obniżenie poziomu metylacji DNA, wpływ na mikroRNA, czy modyfikacje histonów (MENKE i współaut. 2012). Najlepsze efekty $\mathrm{w}$ przypadku leczenia depresji, a $\mathrm{w}$ szczególności w zapobieganiu nawrotom, osiagane sa $\mathrm{w}$ wyniku połaczenia leczenia farmakologicznego $\mathrm{z}$ psychoterapia, $\mathrm{np}$. terapia behawioralna poznawcza (PESELOW i współaut. 2015).

\section{LEKI ANTYDEPRESYJNE OPARTE NA} WYCHWYCIE ZWROTNYM SEROTONINY

W przypadku farmakoterapii jedna $z$ najpopularniejszych grup leków sa inhibitory wychwytu zwrotnego serotoniny (ang. selective serotonin reuptake inhibitors, SSRI). $\mathrm{W}$ patogenezie depresji, zmiany w układzie seretonergicznym moga zachodzić na wielu poziomach i dotyczyć różnych transporterów i receptorów. Jednak jest niezwykle mało prawdopodobne, aby wszystkie te zmiany miały miejsce u każdej osoby chorej na depresję. Czynnikiem wspólnym zaś jest zmniejszenie ilości dostępnej serotoniny $\mathrm{w}$ mózgu. $Z$ tego też względu w latach 80 . ubiegłego wieku na rynku pojawily się SSRI. Do dzisiaj leki te nie stracily nic ze swojej popularności, stosowane sa zarówno $\mathrm{w}$ poczatkowej fazie leczenia depresji, jak również w tzw. leczeniu podtrzymujacym, w celu zapobiegania nawrotom (KAYMAZ i współaut. 2008, GARNOCK-JONES i MCCORMACK 2010). SSRI moduluja działanie transporterów serotoniny $\mathrm{w}$ zakończeniach aksonalnych neuronów serotonergicznych i receptorów dla 5-HT. Dzięki temu, stężenie serotoniny w szczelinie synaptycznej wzrasta, co przekłada się na wzmożenie neuroprzekaźnictwa między komórkami nerwowymi i działanie terapeutyczne.

Jednym $z$ najczęściej stosowanych leków, zaliczanych do SSRI sa: fluoksetyna (wcześniejsza nazwa handlowa to Prozac) i escitalopram, charakteryzujacy się wysoką skutecznością i stosunkowo nielicznymi efektami ubocznymi (CLEVENGER i współaut. 2018).

Do innych, często stosowanych medykamentów w leczeniu depresji należa: inhibitory wychwytu zwrotnego serotoniny i noradrenaliny (SNRI), inhibitory wychwytu zwrotnego noradrenaliny i dopaminy (NDRI), trójpierścieniowe leki antydepresyjne (TCA) i inhibitory monoaminooksydazy (MAOI) (CIPRIANI i współaut. 2009, GARNOCK-JONES i MCCORMACK 2010). Preparaty te wykazuja podobna skuteczność do SSRI (CLEVENGER i współaut. 2018).

\section{KETAMINA - NOWE ROZWIAZANIE W LECZENIU DEPRESJI}

Pomimo iż przez ostatnie dziesięciolecia główny nacisk kładziono na badania inhibitorów zwrotnego wychwytu monoamin, obecnie pojawia się coraz więcej doniesień świadczących o antydepresyjnym działaniu innych substancji. Jedna $z$ najistotniejszych jest ketamina. Ta psychoaktywna substancja jest antagonista receptorów N-metylo-D-asparaginianowych (NMDA) oraz wykazuje silne, aczkolwiek krótkotrwałe działanie przeciwdepresyjne (Kishimoto i współaut. 2016), nawet $\mathrm{w}$ przypadku depresji opornej na konwencjonalne leczenie. Wiadomo, iż podanie ketaminy wywołuje zmiany strukturalne neuronów w przedniej części kory mózgu i w hipokampie. Działanie terapeutyczne tej substancji, rozumiane jako zmiany neurochemiczne i behawioralne, obserwowane jest już po 2 godzinach od podania leku i utrzymuje się do 7 dni (ABDALlAH i współaut. 2015). Uważa się, iż szybkie działanie ketaminy możliwe jest dzięki zainicjowaniu kaskady mechanizmów komórkowych, obejmujacych uwalnianie glutaminianu, aktywację receptorów AMPA, oraz zmian plastycznych w obrebie kory przedczołowej (KRZYSTYNIAK i współaut. 2019, PHAM i GARDIER 2019). Pokazano także, że zmiany w profilu transkrypcyjnym, zachodzace na skutek podania ketaminy, wykazuja podobieństwo do zmian wywołanych działaniem leków przeciwdepresyjnych opartych na zwrotnym wychwycie monoamin. Działanie to $\mathrm{w}$ połaczeniu $z$ blokada receptorów NMDA może stanowić podstawę obserwowanych $\mathrm{w}$ klinice szybkich efektów przeciwdepresyjnych. Ketamina wydaje się być obiecujacym farmaceutykiem w leczeniu depresji, głównie ze względu na szybkie efekty terapeutyczne i zwiazane $z$ tym znaczne zmniejszenie liczby samobójstw.

\section{LECZENIE W OPARCIU O STABILIZATORY NASTROJU}

Do leczenia zaburzeń depresyjnych, głównie $\mathrm{w}$ przypadku choroby afektywnej dwubiegunowej, stosowane sa stabilizatory nastroju (leki normotymiczne). Ograniczaja one nadpobudliwość psychoruchowa i zapobiegaja wahaniom nastroju, a tym samym występowaniu na przemian epizodów depresji i manii. Do głównych leków o takim działaniu zalicza sie sole litu i kwas walproinowy. Niestety niewiele wiadomo na temat mechanizmu działania soli litu. Niemniej jednak wykazują one wysoka skuteczność w leczeniu depresji, chociaż ich stosowanie obarczone jest wysokim ryzykiem wystapienia działań niepożądanych. Kwas walproinowy wpływa 
hamująco na ośrodkowy układ nerwowy, reguluje transport jonów sodu i wapnia przez błony komórkowe oraz podwyższa poziom acetylacji histonów. Jego stosowanie obarczone jest mniejszym ryzykiem działań niepożądanych niż podawanie węglanu litu.

\section{PSYCHOTERAPIA W LECZENIU DEPRESJI}

Psychoterapia często stosowana jest jako wsparcie dla terapii farmakologicznej. W części przypadków pozwala ona na ustalenie przyczyn choroby. Obecnie istnieje wiele odmian psychoterapii. Celem terapii zachowawczych i kognitywnych jest podniesienie samooceny pacjenta i pomoc $\mathrm{w}$ zmianie sposobu postrzegania przez niego najbliższego otoczenia. Ponadto, terapie te minimalizuja ryzyko nawrotu depresji (WATANABE i współaut. 2007).

Kiedy problemem dla pacjenta sa kontakty międzyludzkie, zaleca się stosowanie terapii interpersonalnej. Pomaga ona w rozwiazaniu problemów rodzinnych czy konfliktów w relacjach zawodowych. Polega na przekazywaniu pacjentowi przez terapeutę porad komunikacyjnych. Tego rodzaju terapia odnosi najlepsze skutki w przypadku osób $z$ depresjac umiarkowana (LEMMA i współaut. 2011).

W leczeniu ciężkich przypadków depresji, jako terapię wspierająca stosuje się psychoanalizę. Leczenie przy użyciu tej metody jest czasochłonne, jednak może wprowadzić trwałe zmiany w zachowaniu pacjenta. Istota tej metody jest zidentyfikowanie przyczyny choroby (ZIMMERMANN i współaut. 2015).

\section{ELEKTROWSTRZASY JAKO METODA LECZENIA DEPRESJI}

Wykorzystanie energii elektrycznej do wywołania drgawek $\mathrm{w}$ nadziei na poprawę zdrowia psychicznego osoby chorej stanowi jedna $z$ najbardziej kontrowersyjnych kwestii w dziedzinie zdrowia psychicznego. $Z$ tego względu stosowanie tej metody obarczone jest wieloma watpliwościami natury moralnej i etycznej (AsIOLI i FIORITTI 2000). Jednak metoda ta stosowana jest od ponad 80 lat i uważa się, że uratowała lub znacznie poprawiła życie dziesiątek tysięcy pacjentów (GAZDAG i współaut. 2009). Dzisiaj uważana jest za bezbolesna, względnie bezpieczna i skuteczna formę leczenia depresji, zarówno w przypadku dorosłych, jak i dzieci.

Przy wyborze odpowiedniego sposobu leczenia, należy brać pod uwagę skuteczność danego leku/terapii w odniesieniu do konkretnych objawów występujących u pacjenta, a także efektywność leczenia, nie tyl- ko podczas trwającego epizodu depresji, ale także w zapobiegania jego nawrotom.

\section{PODSUMOWANIE}

W niniejszej pracy opisano krótko najważniejsze kierunki badawcze w zakresie patogenezy depresji i jej leczenia. Pomimo prowadzenia licznych badań, wiedza o depresji jest ciagle bardzo ograniczona, a bez zrozumienia patogenezy depresji nie znajdziemy metody skutecznego jej leczenia. Nasze dzisiejsze rozumienie depresji jest pełne luk, głównie w zakresie relacji pomiędzy zaburzeniami fizjologicznymi, poznawczymi, objawami klinicznymi oraz skutkami różnych metod leczenia. $Z$ tego względu ważnym wyzwaniem dla przyszłych badań będzie opracowanie ogólnej teorii, łączącej w logiczna całość wszystkie obserwacje. Na przykład, jaki jest związek mię$\mathrm{dzy}$ zaburzeniami w działaniu neuroprzekaźników a podwyższonym poziomem kortyzolu i zmianami objętości hipokampa, a także, jaki mechanizm powoduje, że różne podejścia terapeutyczne (psychoterapia, farmakoterapia, elektrowstrzasy) wywołuja ten sam efekt terapeutyczny.

\section{Streszczenie}

Patogeneza depresji jest wciąz słabo poznana. Badania naukowe postuluja, że istotna role pełnia nieprawidłowości w przekaźnictwie serotonergicznym, na co wskazuje skuteczność działania leków powodujacych zahamowanie wychwytu zwrotnego serotoniny. Farmaceutyki te działają $z$ opóźnieniem, co sugeruje ich pośredniczenie w zmianach długoterminowych, takich jak zmiany ekspresji genów czy efekty epigenetyczne. Wiadomo także, że w rozwój depresji zaangażowane sa hormony glukokortykoidowe oraz czynniki neurotroficzne (BDNF).

\section{PODZIĘKOWANIA}

Autorka dziękuje prof. dr hab. Grzegorzowi Wilczyńskiemu i prof. dr hab. Andrzejowi Wróblowi za pomoc oraz cenne uwagi i komentarze dotyczace niniejszego artykułu.

\section{LITERATURA}

AbDallah C. G., Averill L. A., Krystal J. H., 2015. Ketamine as a promising prototype for a new generation of rapid-acting antidepressants. Ann. NY Acad. Sci. 1344, 66-77.

Alt S. R., Turner J. D., KlOK M. D., MeiJer O. C., LAKke E. A., DeriJK R. H., Muller C. P., 2010. Differential expression of glucocorticoid receptor transcripts in major depressive disorder is not epigenetically programmed. Psychoneuroendocrinology 35, 544-556.

AMERICAN PSYCHIATRIC ASSOCIATION, 2013a. APA Practice Guideline for the Treatment of $\mathrm{Pa}$ tients with Major Depressive Disorder. 3rd edition. Arlington, Virginia.

AMERICAN PSYCHIATRIC ASSOCIATION, 2013b. Diagnostic and Statistical Manual of Mental Disorders, Fifth Edition. Arlington, Virginia. 
ANACKer C., Zunszain P. A., CARVAlho L. A. PARIANTE C. M., 2011. The glucocorticoid receptor: pivot of depression and of antidepressant treatment? Psychoneuroendocrinology 36, 415-425.

ANDERSON I. M., PARRY-BILlings M., NEWSHOlME E. A., Poortmans J. R., COWEN P. J., 1990. Decreased plasma tryptophan concentration in major depression: relationship to melancholia and weight loss. J. Affect. Disord. 20, 185191.

ARCHER T., OSCAR-BERMAN M., Blum K., GOLD M., 2013. Epigenetic modulation of mood dis orders. J. Genet. Syndr. Gene Therapy 4, 1000120 .

ASIOLI F., FIORITTI A., 2000. Electroshock (ESK) and electroconvulsive therapy (ECT). Epidemiol. Psichiat. Social. 9, 99-102

BAle T. L., BARAM T. Z., BROWN A. S., Goldstein J. M., INSEL T. R., MCCARTHY M. M., NEMEROfF C. B., Reyes T. M., Simerly R. B., SusSER E. S., NESTLER E. J., 2010. Early life programming and neurodevelopmental disorders. Biol. Psychiatry 68, 314-319.

BECHTHOLT-GOMPF A. J., WAlther H. V., ADAMS M. A., CARlezon W. A. JR., Ongur D., COHEN B. M., 2010. Blockade of astrocytic glutamate uptake in rats induces signs of anhedonia and impaired spatial memory. Neuropsychopharmacology 35, 2049-2059.

BHAGWAGAR Z., COWEN P. J., 2008. It's not over when it's over: persistent neurobiological abnormalities in recovered depressed patients. Psychol. Med. 38, 307-313.

Bhagwagar Z., RABINER E. A., SARgent P. A., GRAsbY P. M., COWEN P. J., 2004. Persistent reduction in brain serotonin $1 A$ receptor binding in recovered depressed men measured by positron emission tomography with [11C]WAY100635. Mol. Psychiatry 9, 386-392.

BINDER E. B., 2009. The role of FKBP5, a co-chaperone of the glucocorticoid receptor in the pathogenesis and therapy of affective and anxiety disorders. Psychoneuroendocrinology 34, S186-S195.

BRINK A., 1979. Depression and loss: a theme in Robert Burton's "Anatomy of melancholy" (1621). Can. J. Psychiatry 24, 767-772.

BROWN E. S., 2009. Effects of glucocorticoids on mood, memory, and the hippocampus. Treatment and preventive therapy. Ann. NY Acad. Sci. 1179, 41-55.

CARR G. V., LUCKY I., 2010. The role of serotonin in depression. [W:] Handbook of Behavioral Neuroscience. MÜlLER CH. P, JACOBS B. L. (red.). ScienceDirect 21, 493-505.

Chung W. S., Allen N. J., Eroglu C., 2015. Astrocytes Control Synapse Formation, Function, and Elimination. Cold Spring Harb Perspect Biol 7, a020370.

Cipriani A., Furukawa T. A., Salanti G., Geddes J. R., Higgins J. P., Churchill R., WatanaBe N., NAKagawa A., OMORI I. M., MCGUIRE H. TANSElla M., BARBUI C., 2009. Comparative efficacy and acceptability of 12 newgeneration antidepressants: a multiple-treatments meta-analysis. Lancet 373, 746-758.

Cipriani A., Furukawa T. A., Salanti G., ChaimaNI A., ATKINSON L. Z., OGAWA Y., LEUCHT S., RuHE H. G., Turner E. H., Higgins J. P. T., EGGER M., TAKESHIMA N., HAYASAKA Y., IMAI H., SHINOHARA K., TAJIKA A., IOANNIDIS J. P. A., GEDDES J. R., 2018. Comparative efficacy and acceptability of 21 antidepressant drugs for the acute treatment of adults with major depressive disorder: a systematic review and network meta-analysis. Lancet 391, 1357 1366.

Clevenger S. S., Malhotra D., Dang J., Vanle B., ISHAK $\mathrm{W}$. W., 2018. The role of selective serotonin reuptake inhibitors in preventing relapse of maljor depressive disorder. Ther. Adv. Psychopharmacol. 8, 49-58.

COWEN P. J., 2015. Neuroendocrine and neurochemical processes in depression. [W:] The Oxford Handbook of Mood Disorders. DERUBEIS R. J., STRUNK D. R. (red.). Oxford: Oxford University Press, 190-200.

Crepaldi L., Policarpi C., CoATti A., Sherlock W. T., Jongbloets B. C., Down T. A., RicciO A., 2013. Binding of TFIIIC to sine elements controls the relocation of activity-dependent neuronal genes to transcription factories. PLoS Genet. 9, e1003699.

Cui W., Mizukami H., Yanagisawa M., Aida T., NOMURA M., ISOMURA Y., TAKAYANAGI R., OZAWA K., TANAKA K., AIZAWA H., 2014. Glial dysfunction in the mouse habenula causes depressive-like behaviors and sleep disturbance. J. Neurosci. 34, 16273-16285.

Dedoni S., Olianas M. C., Ingianni A., Onali P., 2012. Type I interferons impair BDNF-induced cell signaling and neurotrophic activity in differentiated human SH-SY5Y neuroblastoma cells and mouse primary cortical neurons. J. Neurochem. 122, 58-71.

De Kloet E. R., VReugdenhil E., Oitzl M. S., JOËLS M., 1998. Brain corticosteroid receptor balance in health and disease. Endocr. Rev. 19, 269-301.

DE SousA A., 2011. Freudian theory and consciousness: a conceptual analysis. Mens. Sana Monogr. 9, 210-217.

DREVeTS W. C., Furey M. L., 2009. Depression and the Brain. Encyclopedia of Neuroscience, Academic Press, 459-470.

FARRELl C., O'KEANE V., 2016. Epigenetics and the glucocorticoid receptor: A review of the implications in depression. Psychiatry Res. 242, 349-356.

FERGUSSON D. M., Horwood L. J., Lynskey M. T., 1996. Childhood sexual abuse and psychiatric disorder in young adulthood. II. Psychiatric outcomes of childhood sexual abuse. J. Am. Acad. Child Adolesc. Psychiatry 35, 13651374.

FRANCE C. M., LYSAKeR P. H., ROBINSON R. P., 2007. The "chemical imbalance" explanation for depression: Origins, lay endorsement, and clinical implications. Profes. Psychol. Res. Pract. 38, 411-420.

FRIEDRICH M. J., 2017. Depression is the leading cause of disability around the world. JAMA 317, 1517.

Fuller P. J., Lim-Tio S. S., BRENNAN F. E., 2000. Specificity in mineralocorticoid versus glucocorticoid action. Kidney Int. 57, 1256-1264.

GARNOCK-JONES K. P., MCCORMACK P. L., 2010. Escitalopram: a review of its use in the management of major depressive disorder in adults. CNS Drugs 24, 769-796.

GAUDIANO B. A., 2008. Cognitive-behavioural therapies: achievements and challenges. Evid. Based Ment. Health 11, 5-7.

GAZDAG G., BITTER I., UNGVARI G., BARAN B., 2009. Convulsive therapy turns 75. Brit. J. Psychiatry 194, 387-388.

Gryglewski G., LANZENBERGER R., KRANZ G. S., Cumming P., 2014. Meta-analysis of molecular imaging of serotonin transporters in major depression. J. Cerebral Blood Flow Metab. 34, 1096-1103. 
HARRISON P. J., 2002. The neuropathology of primary mood disorder. Brain 125, 1428-1449

HAYLEY S., LiTTELJOHN D., 2013. Neuroplasticity and the next wave of antidepressant strategies. Front. Cell. Neurosci. 7, 218.

Heim C., NewPort D. J., Mletzko T., Miller A. H., NEMEROFF C. B., 2008. The link between childhood trauma and depression: insights from HPA axis studies in humans. Psychoneuroendocrinology 33, 693-710.

Heim C., ShugarT M., CRAighead W. E., NEMEROFF C. B., 2010. Neurobiological and psychiatric consequences of child abuse and neglect. Develop. Psychobiol. 52, 671-690.

Herman J. P., MCKLVEen J. M., Ghosal S., KopP B., Wulsin A., MAKINSON R., ScheimanN J., MYERS B., 2016. Regulation of the hypothalamic-pituitary-adrenocortical stress response. Comp. Physiol. 6, 603-621.

HiRVONEN J., KARLSSON H., KAJANDER J., LEPOla A., MarkKula J., Rasi-HaKala H., Nagren K. SAlMinen J.K., Hietala J., 2008. Decreased brain serotonin 5-HT1A receptor availability in medication-naive patients with major depres sive disorder: an in-vivo imaging study using $P E T$ and [carbonyl-11C/WAY-100635. Int. J. Neuropsychopharmacol. 11, 465-476.

HoRNUNG O. P., HEIM C. M., 2014. Gene-environment interactions and intermediate phenotypes: early trauma and depression. Front. Endocrinol. 5, 14.

Howard D. M., AdAms M. J., Clarke T. K., HaFFERTY J. D., GIBSON J., SHIRALI M., COLEMAN J. R. I., HAGENAARS S. P., WARD J., WIGMORE E. M., Alloza C., Shen X., Barbu M. C., XU E. Y., Whalley H. C., Marioni R. E., Porteous D. J., Davies G., Deary I. J., Hemani G. BERGER K. i współaut., 2019. Genome-wide meta-analysis of depression identifies 102 independent variants and highlights the importance of the prefrontal brain regions. Nat Neurosci. 22, 343-352.

JANS L. A., RIEDEL W. J., MARKUS C. R., BlOKLAND A., 2007. Serotonergic vulnerability and depression: assumptions, experimental evidence and implications. Mol. Psychiatry 12, $522-543$

KANG H. J., VOleti B., HaJSzan T., RAJKOWSKA G., STOCKMEIER C. A., LICZNERSKI P., LEPACK A., MAJIK M. S., JEONG L. S., BANASR M., SON H., DUMAN R. S., 2012. Decreased expression of synapse-related genes and loss of synapses in major depressive disorder. Nat. Med. $18,1413-1417$.

Kavalali E. T., Monteggia L. M., 2012. Synaptic mechanisms underlying rapid antidepressant action of ketamine. Am. J. Psychiatry 169, 1150-1156.

Kaymaz N., Van Os J., LoONEN A. J., NOLEN W. A., 2008. Evidence that patients with single versus recurrent depressive episodes are differentially sensitive to treatment discontinuation: a meta-analysis of placebo-controlled randomized trials. J. Clin. Psychiatry 69, 14231436.

KRISHNAN V., NESTLER E. J., 2008. The molecular neurobiology of depression. Nature 455, 894902.

KRISHNAN V., NESTLER E. J., 2010. Linking molecules to mood: new insight into the biology of depression. Am. J. Psychiatry 167, 13051320.

Kishimoto T., Chawla J. M., Hagi K., Zarate C. A., KANE J. M., BAUER M., CORREll C. U., 2016. Single-dose infusion ketamine and non-ketamine $N$-methyl-D-aspartate receptor antagonists for unipolar and bipolar depression: A meta-analysis of efficacy, safety and time trajectories. Psychol. Med. 46, 14591472

KRZYSTYNIAK A., BACZYNSKA E., MAGNOWSKA M., ANTONIUK S., ROSZKOWSKA M., ZAREBA-KOZIOL M., DAS N., BASU S., PIKULA M., WLODARCZYK J., 2019. Prophylactic ketamine treatment promotes resilience to chronic stress and accelerates recovery: Correlation with changes in synaptic plasticity in the CA3 subregion of the hippocampus. Int. J. Mol. Sci. 20, 1726.

Le Francois B., CZesak M., Steubl D., AlberT P. R., 2008. Transcriptional regulation at a HTR1A polymorphism associated with mental illness. Neuropharmacology 55, 977-985.

LEE Y., GASKINS D., ANAND A., SHEKHAR A., 2007. Glia mechanisms in mood regulation: a novel model of mood disorders. Psychopharmacolog 191, 55-65.

LEMma A., TARget M., Fonagy P., 2011. The development of a brief psychodynamic intervention (dynamic interpersonal therapy) and its application to depression: A pilot study. Psychiatry Interpers. Biol. Proc. 74, 41-48.

LIPSKY R. H., MARINI A. M., 2007. Brain-derived neurotrophic factor in neuronal survival and behavior-related plasticity. Ann. NY Acad. Sci. $1122,130-143$.

LOLAK S., SuWANNARAT P., LIPSKY R. H., 2014. Epigenetics of depression. Progr. Mol. Biol. Transl. Sci. 128, 103-137.

Maes M., Jacobs M. P., Suy E., Minner B., LeClercQ C., Christiaens F., Raus J., 1990. Suppressant effects of dexamethasone on the availability of plasma L-tryptophan and tyrosine in healthy controls and in depressed patients. Acta Psychiatr. Scand. 81, 19-23.

MANIGLIO R., 2009. The impact of child sexual abuse on health: a systematic review of reviews. Clin. Psychol. Rev. 29, 647-657.

ManjI H. K., DREveTS W. C., CHARNEY D. S., 2001. The cellular neurobiology of depression. Nat. Med. 7, 541-547.

MANN J. J., CURRIER D., 2006. Effects of genes and stress on the neurobiology of depression. Int. Rev. Neurobiol. 73, 153-189.

MCGOWAN P. O., SASAKI A., D'Alessio A. C., DYMOV S., LABONTÉ B., SZYF M., TURECKI G., MEANEY M. J., 2009. Epigenetic regulation of the glucocorticoid receptor in human brain associates with childhood abuse. Nat. Neurosci. $12,342-348$.

MCGuffin P., COHEN S., KNIGHT J., 2007. Homing in on depression genes. Am. J. Psychiatry $164,195-197$.

Menke A., Klengel T., Binder E. B., 2012. Epigenetics, depression and antidepressant treatment. Curr. Pharm. Des. 18, 5879-5889.

MOHAMMAD-ZADEH L. F., MOSES L., GWALTNEY-BRANT S. M., 2008. Serotonin: a review. J. Vet. Pharmacol Ther. 31, 187-199.

MONDIMORE F. M., 2005. Kraepelin and manic-depressive insanity: an historical perspective. Int. Rev. Psychiatry 17, 49-52

Murgatroyd C., PATCHEV A. V., Wu Y., MicAle V., BOCKMUHL Y., Fischer D., HOLSBOER F., WOtJAK C. T., Almeida O. F., SPEnGleR D., 2009. Dynamic DNA methylation programs persistent adverse effects of early-life stress. Nat. Neurosci. 12, 1559-1566.

NARANJO C. A., TREMBLAY L. K., BUSTO U. E., 2001. The role of the brain reward system in depression. Prog Neuropsychopharmacol Biol. Psychiatry. 25, 781-823. 
Neumeister A., Nugent A. C., Waldeck T., GeraCI M., SchwarZ M., BONNE O., BAIN E. E., LuCKENBAugh D. A., HeRsCOVITCH P., ChaRNEY D. S., DREVETS W. C., 2004. Neural and behavioral responses to tryptophan depletion in unmedicated patients with remitted major depressive disorder and controls. Arch. Gen. Psychiatry, 61, 765-773.

NEUMEISTER A., YUAN P., YOUnd T. A., BONNE O., LuCKenbaugh D. A., Charney D. S., MANJI H., 2005. Effects of tryptophan depletion on serum levels of brain-derived neurotrophic factor in unmedicated patients with remitted depression and healthy subjects. Am. J. Psychiatry. 162, 805-807.

Nimchinsky E. A., SABatini B. L., Svoboda K., 2002. Structure and function of dendritic spines. Ann. Rev. Physiol. 64, 313-353.

O'Keane V., Frodl T., Dinan T. G., 2012. A review of atypical depression in relation to the course of depression and changes in HPA axis organization. Psychoneuroendocrinology 37, 1589-1599.

Oray M., ABU SAMra K., Ebrahimiadib N., MEese H., FOSTER C. S., 2016. Long-term side effects of glucocorticoids. Expert Opin. Drug Safety, $15,457-465$

PEselow E. D., TOBIA G., Karamians R., Pizano D., ISHAK W. W., 2015. Prophylactic efficacy of fluoxetine, escitalopram, sertraline, paroxetine, and concomitant psychotherapy in major depressive disorder: outcome after long-term follow-up. Psychiatry Res. 225, 680-686.

Peters A., Palay S. L., Webster H., 1991. The fine structure of the nervous system. Neurons and their supporting cells. Oxford University Press, Nowy Jork.

PHAM T. H., GARDIER A. M., 2019. Fast-acting antidepressant activity of ketamine: highlights on brain serotonin, glutamate, and GABA neurotransmission in preclinical studies. Pharmacol. Therapeut. 199, 58-90.

PitTEnGeR C., Duman R. S., 2008. Stress, depression, and neuroplasticity: a convergence of mechanisms. Neuropsychopharmacology 33, 88-109.

QiaO H., Li M. X., Xu C., Chen H. B., AN S. C., MA X. M., 2016. Dendritic spines in depression: what we learned from animal models. Neural Plast. 2016, 8056370.

RAJARAJAN P., GIL S. E., BRENNAND K. J., AKBARIAN S., 2016. Spatial genome organization and cognition. Neuroscience 17, 681-691.

RAJARAJAN P., BORRMAN T., LiaO W., Schrode N., FlaHERTY E., CASIÑO C., POWELl S., YASHASWINI C., LAMARCA E. A., KASSIM B., JAVIDFAR B., ESPESO-GIL S., LI A., WON H., GESCHWIND D. H., Ho S. M., Macdonald M., HOFFMAN G. E., Roussos P., ZHANG B., HaHn C. G., WENG Z., BRENNAND K. J., AKBARIAN S., 2018. Neuron-specific signatures in the chromosomal connectome associated with schizophrenia risk. Science 236, eaat4311.

RAJKowska G., STOCKMEIER C.A., 2013. Astrocyte pathology in major depressive disorder: insight from human postmortem brain tissue. Curr. Drug Targets 14, 1225-1236.

RAMAMOORTHY S., CIDLOWSKI J. A., 2013. Ligand-induced repression of the glucocorticoid receptor gene is mediated by an NCoR 1 repression complex formed by long-range chromatin interactions with intragenic glucocorticoid response elements. Mol. Cell. Biol. 33, 1711-1722.
REYNOLDS E. H., WILSON J. V., 2013. Depression and anxiety in Babylon. J. R. Soc. Med. 106, $478-481$.

Roth T. L., LUBin F. D., FUnK A. J., SweatT J. D., 2009. Lasting epigenetic influence of early-life adversity on the BDNF gene. Biol. Psychiatry 65, 760-769.

RÖSSLER W., 2016. The stigma of mental disorders: A millennia-long history of social exclusion and prejudices._EMBO Rep. 17, 12501253.

RUHÉ H. G., MASON N. S., SCHENE A. H., 2007. Mood is indirectly related to serotonin, norepinephrine and dopamine levels in humans: a meta-analysis of monoamine depletion studies. Mol. Psychiatry 12, 331-359.

Rush A. J., TRIVEDI M. H., WISNIEWSKI S. R., NIERENBERG A. A., STEWART J. W., WARDEN D., Niederehe G., Thase M. E., Lavori P. W., LEBOWITZ B. D., MCGRATH P. J., ROSENBAUM J. F., SACKeim H. A., Kupfer D. J., LuTHeR J., FAVA M., 2006. Acute and longer-term outcomes in depressed outpatients requiring one or several treatment steps: a $S T A R{ }^{*} D$ report. Am. J. Psychiatry 163, 1905-1917.

SANACORA G., BANASR M., 2013. From pathophysi ology to novel antidepressant drugs: glial contributions to the pathology and treatment of mood disorders. Biol. Psychiatry 73, 11721179.

SAPOLSKY R. M., 2000 Glucocorticoids and hippocampal atrophy in neuropsychiatric disorders. Arch. Gen. Psychiatry 57, 925-935.

SHIMIZU E., HASHIMOTO K., OKAMURA N., KOIKE K., KOMATSU N., KumaKiri C., NAKAzATO M., WATANABE H., SHINODA N., OKADA S., IYO M., 2003. Alterations of serum levels of brainderived neurotrophic factor (BDNF) in depressed patients with or without antidepressants. Bio Psychiatry 54, 70-75.

Smart C., Strathdee G., Watson S., Murgatroyd C., MCAllister-Williams R. H., 2015. Early life trauma, depression and the glucocorticoid receptor gene - an epigenetic perspective. Psychol. Med. 45, 3393-3410.

SMOAK K. A., CIDLOWSKI J. A., 2004. Mechanisms of glucocorticoid receptor signaling during in flammation. Mech. Ageing Dev. 125, 697-706.

SKuPIO U., TERTIL M., SiKORA M., GOlDA S., WAWRZCZAK-BARGIELA A., PRZEWLOCKI R., 2015. Behavioral and molecular alterations in mice resulting from chronic treatment with dexmethasone: relevance to depression. Neuroscience 286, 141-150.

SOBOCKI P., JÖNSSON B., ANGST J., REHNBERG C., 2006. Cost of depression in Europe. J. Ment. Health Policy Econ. 9, 87-98.

STEINHÄUSER C., KETTENMANN H., 2009. Astrocyte: Neurotransmitter and Hormone Receptors. Encyclopedia of Neuroscience, 579-585.

Stephens M. A., WAND G., 2012. Stress and the HPA axis: role of glucocorticoids in alcohol dependence. Alcohol Res. Curr. Rev. 34, 468483.

Sun H., Kennedy P. J., Nestler E. J., 2013. Epigenetics of the depressed brain: role of histone acetylation and methylation. Neuropsychopharmacology 38, 124-137.

SZCZERBAL I., FOSTER H. A., BRIDGER J. M., 2009. The spatial repositioning of adipogenesis genes is correlated with their expression status in a porcine mesenchymal stem cell adipogenesis model system. Chromosoma 118, 647-663.

TANG Z. LUO O. J., LI X., ZHENG M., ZHU J. J., SZALAJ P., TRZASKOMA P., MAGALSKA A., WLODARCZYK J., RUSZCZYCKI B., MICHALSKI P., 
Piecuch E., Wang P., Wang D., Tian S. Z., PENRAD-Mobayed M., SACHS L. M., RUaN X., Wei C. L., LiU E. T., Wilczynski G. M., PleWCZYNSKI D., LI G., RUAN Y., 2015. CTCF-Mediated human $3 D$ genome architecture reveals chromatin topology for transcription. Cell 163, 1611-1627.

TiPTON C. M., 2014. The history of "Exercise Is Medicine" in ancient civilizations. Adv. Physiol. Educ. 38, 109-117.

Tsankova N., Renthal W., Kumar A., Nestler E. J., 2007. Epigenetic regulation in psychiatric disorders. Nat. Rev, Neurosci. 8, 355-367.

Uher R., TANSey K. E., DeW T., Maier W., Mors O., Hauser J., DernovseK M. Z., HenigsBERG N., Souery D., FARMer A., MCGuffin P., 2014. An inflammatory biomarker as a differential predictor of outcome of depression treatment with escitalopram and nortriptyline. Am. J. Psychiatry $171,1278-1286$.

VOlTERRA A., 2009. Neurotransmitter Release from Astrocytes. Encyclopedia of Neuroscience, 1061-106.

WAINWRIGHT S. R., GALEA L. A., 2013. The neural plasticity theory of depression: assessing the roles of adult neurogenesis and PSA-NCAM within the hippocampus. Neural. Plast. 2013, 805497.

WALCZAK A., SZCZEPANKIEWICZ A. A., RUSZCZYCKI B., Magalska A., Zamlynska K., DZWONEK J., WILCZEK E., ZYBURA-BRODA K., RYLSKI M., MALINOWSKA M., DABROWSKI M., SZCZEPINSKA T., PAWLOWSKI K., PYSKATY M., WLODARCZYK J., SZCZERBAL I., SWITONSKI M., CREMER M., WIL-
CZYNSKI G. M., 2013. Novel higher-order epigenetic regulation of the Bdnf gene upon seizures. J Neurosci. 33, 2507-2511.

Wang Q., Jie W., LiU J. H., Yang J. M., GaO T. M., 2017. An astroglial basis of major depressive disorder? An overview. Glia 65, 12271250

Watanabe N., Hunot V., Omori I. M., Churchill R., FURUKAWA T. A., 2007. Psychotherapy for depression among children and adolescents: a systematic review. Acta Psychiatr. Scand. 116, 84-95.

Wichers M., Geschwind N., Van Os J., Peeters F., 2010. Scars in depression: Is a conceptual shift necessary to solve the puzzle? Psychol. Med. 40, 359-365.

WidOM C. S., DUMONT K., CZAJA S. J., 2007. A prospective investigation of major depressive disorder and comorbidity in abused and neglected children grown up. Arch. Gen. Psychiatry 64, 49-56.

WILCZYNSSKI G. M., 2014. Significance of higher-order chromatin architecture for neuronal function and dysfunction, Neuropharmacology 80, 28-33.

WORLD HEALTH ORGANIZATION, 2017. Depression and other common mental disorders: Global Health Estimates Geneva.

ZimMERMANN J., LÖFFLER-STASTK H., HuBER D., Klug G., AlhabBo S., Bock A., BEnECKe C., 2015. Is it all about the higher dose? Why psychoanalytic therapy is an effective treatment for major depression. Clin. Psychol. Psychother. 22, 469-487.

KOSMOS Vol. 69, 1, 169-183, 2020

\section{Katarzyna Karolina Pels}

Laboratory of Molecular and Systemic Neuromorphology, Nencki Institute of Experimental Biology PAS, 3 Pasteur Str., 02-093

Warszawa,E-mail:k.pels@nencki.edu.pl

\section{MOLECULAR PATHOGENESIS OF STRESS AND DEPRESSION}

\section{Summary}

The pathogenesis of depression is still poorly understood. Abnormalities in serotonergic transmission are postulated to be a crucial player in this disorder. That is indicated by the effectiveness of drugs acting by inhibition of serotonin reuptake. These pharmaceuticals act with a delay, suggesting that they mediate long-term changes, such as changes in gene expression or epigenetic effects. It is also known that glucocorticoid hormones and neurotrophic factors (BDNF) are involved in depression development.

Key words: depression, depression treatment, disruptions of serotonergic system, epigenetics of depression, glucocorticoids, HPA axis, stress 